\title{
НАБУТТЯ СТАТУСУ ПРЕДСТАВНИКА ПРАВНИЧОЇ ДОПОМОГИ
}

Чорнобривець В. В.

У науковій статmі досліджено процес набуття статусу представника правничої допомоги. Зазначено, що правова допомога в різних країнах світу надається адвокатами в широкому розумінні цього слова, тобто особами, що мають юридичну освіту, юридичний стаж, склали відповідний екзамен та отримали право надання правової допомоги. Усі ці вимоги щодо адвоката (особи, наділеної правом надання правової допомоги) встановлюються положеннями внутрішнього права окремих країн.

Проаналізовано зарубіжний досвід здобуття вищоі юридичної освіти. Розглянуто напрям реформування адвокатури в Україні та наголошено, що підвищення статусу адвокатської професії як еліти громадянського суспільства, встановлення єдиних вимог доступу до адвокатської діяльності, рівність осіб, що претендують на набуття статусу адвоката, встановлення єдиних етичних $i$ професійних стандартів адвокатури є благородними цілями реформи адвокатури, що у світлі нових законопроектів цілком можуть бути реалізованими.

Ключові слова: правнича допомога, адвокат, адвокатська діяльність, юридична освіта, стажування, кваліфікаційний icnum.

В научной статье исследован процесс получения статуса представителя юридической помощи. Отмечено, что правовая помощь в различных странах мира оказывается адвокатами в широком смысле этого слова, то есть лицами, имеющими юридическое образование, юридический стаж, сдали соответствующий экзамен и получили право предоставления правовой помощи.

Проанализирован зарубежный опыт получения высшего юридического образования. Рассмотрено направление реформирования адвокатуры в Украине и отмечено, что повышение статуса адвокатской профессии как элиты гражданского общества, установление единых требований доступа к адвокатской деятельности, равенство лиц, претендующих на приобретение статуса адвоката, уста новление единых этических и профессиональных стандартов адвокатуры являются благородными целями реформы адвокатуры, что в свете новых законопроектов вполне могут быть реализованы.

Ключевые слова: юридическая помощь, адвокат, адвокатская деятельность, юридическое образование, стажировки, квалификационный экзамен.

In the scientific article the process of acquiring the status of a representative of legal assistance is researched. It is noted that legal aid in different countries of the world is provided by lawyers in the broad sense of the word, that is, those who have legal education, legal experience, passed the relevant exam and received the right to provide legal assistance. The foreign experience of obtaining higher legal education is analyzed. The direction of advocacy reform in Ukraine is considered.

The foreign experience of obtaining higher legal education is analyzed. Considered the direction of reforming the advocacy in Ukraine and it is emphasized that the increase of the status of the advocate's profession as an elite of civil society, the establishment of common requirements for access to advocacy, the equality of persons applying for the status of a lawyer, the

Чорнобривець В. В., 2019 establishment of common ethical and professional standards for advocacy are noble goals of the reform of the Bar, in the light of new bills, may well be realized.

To date, a bill has been registered in Ukraine, which proposes to improve the norms of the current Ukrainian legislation on advocacy and advocacy in terms of procedures and peculiarities of obtaining the status of a lawyer.

The draft Law is to amend the Law of Ukraine "On Advocacy and Advocacy" and stipulates that higher law education should be understood as the second (master's) level of higher legal education received in Ukraine, as well as higher legal education of the corresponding level obtained in foreign states and recognized in Ukraine in accordance with the procedure established by law.

The bill also provides an exhaustive list of grounds for refusal to admit to the qualification examination: the applicant's mismatch with the requirements of the Law of Ukraine "On Advocacy and Advocacy"; the inconsistency of the submitted documents with the requirements of the law; the submission is not in full scope of the documents provided for by the procedure for admission to the qualification examination. The project introduces a qualification examination through anonymous testing. It is also proposed that testing should be carried out by the Higher Qualification-Disciplinary Commission of Advocacy, and organizationally promoted by the Qualification-Disciplinary Commissions of the Regions

Key words: legal aid, lawyer, advocacy, legal education, internship, qualification examination.

Постановка проблеми. Надання особі правничої допомоги $є$ пріоритетним напрямом кожної демократичної держави. Правова допомога повинна сприяти забезпеченню безпеки правового обороту в державі та виконувати роль інструменту захисту прав особи, зокрема реалізації іiї права доступу до судочинства.

Тому велику роль відіграє те, хто може надавати правову допомогу та в яких межах, оскільки від фаховості правової допомоги, що надається, залежить на скільки цей інститут виконує покладені на нього функції забезпечення безпеки правового обороту та реалізації прав і свобод особи.

Аналіз останніх досліджень і публікацій. На доктринальному рівні окремі аспекти професійної правничої (правової) допомоги досліджували такі вітчизняні та зарубіжні вчені як М.М. Антонович, О.А. Банчук, А. Батлер, Е. Бланкенбург, Є.Ю. Бова, В.В. Букач, М.В. Вітрук, Р.Ф. Гринюк, Д.А. Гудима, М.М. Гультай, С.Д. Гусарєв, В.О. Демиденко, М.С. Демкова, С.П. Добрянський, В.М. Ісакова, Б.В. Калиновський, Н.В. Камінська, Н.І. Карпачова, Р. Кассен, М. Кіку, А.М. Колодій, А.Т. Комзюк, В.В. Копєйчиков, В.О. Котюк, М. Кузінс, Р.О. Куйбіда, В.С. Личко, М.Т. Лоджук, О.М. Лощихін, П.О. Недбайло, С.С. Немченко, С.В. Оверчук, В.Ф. Опришко, В.Ю. Панченко, В.В. Печерський, В.Ф. Погорілко, С.В. Прилуцький, П.М. Рабінович, Ф. Реган, О.Ф. Скакун, О.В. Скрипнюк, Р. Сміт, М.В. Стаматіна, П.Б. Стецюк, Г.Ж. Сулейменова, М.О. Теплюк, Р.С. Титикало, Ю.М. Тодика, Ю.С. Шемшученко, Ю.Т. Шрамко, О.В. Шубейкіна, О.Г. Юшкевич та інші. 
Мета статті полягає у розкритті основних вимог до представника правничої допомоги в Україні та в інших країнах світу.

Виклад основного матеріалу. Правова допомога в різних країнах світу надається адвокатами в широкому розумінні цього слова, тобто особами, що мають юридичну освіту, юридичний стаж, склали відповідний екзамен та отримали право надання правової допомоги. Усі ці вимоги щодо адвоката (особи, наділеної правом надання правової допомоги) встановлюються положеннями внутрішнього права окремих країн.

Для того щоби стати адвокатом, потрібна перш за все вища юридична освіта. В Україні, щоби стати бакалавром права, треба навчатися чотири роки, при цьому спочатку студенти навчаються за загальним планом і лише під кінець навчання або взагалі в магістратурі відбувається спеціалізація за певними галузями права. Після здобуття освітньо-кваліфікаційного рівня «бакалавр» студент може продовжити навчання для здобуття освітньо-кваліфікаційного рівня «магістр". Навчання в магістратурі зазвичай триває два роки [8].

У Німеччині навчання в університеті займає так само не менше чотирьох років, і це якщо скласти іспити з першого разу та вчасно. Інакше навчання може затягнутись. Очевидно, вчитись досить складно - за статистикою, третина студентів вирішує вибрати іншу сферу діяльності вже на третьому році навчання.

У Франції навчання триває 18 місяців і ділиться на три рівні кожний по шести місяців. Упродовж 18-ти місяців той, хто бажає стати адвокатом, має змогу отримувати необхідні знання, при цьому вивчення предметів відбувається за принципом «Від простого до складнішого». Тобто на першому рівні вивчаються певні базові предмети: статус адвоката, професійна етика, практичні аспекти адвокатської діяльності тощо. Другий рівень передбачає вибір індивідуальної програми. Ідеться про предмети, що безпосередньо стосуються майбутньої сфери діяльності: ця програма допомагає пізніше влитись у сферу адвокатської діяльності. На третьому рівні студенти вже проходять стажування [7, с. 32].

У США навчання триває сім років: спочатку студент чотири роки навчається в коледжі, а потім ще три роки - у правничій школі. При цьому перші чотири роки $\epsilon$ спільними - досить часто у правничих школах можна зустріти колишніх економістів, математиків, фізиків тощо. Правничих шкіл у США $є$ велика кількість і на будь-який смак від знаних і дорогих, наприклад, Гарварда чи Колумбійського університету, до простіших, які не потребують значних фінансових затрат, але при цьому також можуть дати непогану юридичну освіту, наприклад, Фордхем [7, с. 33].

Варто зазначити, що, на відміну від українських вишів, які переважно орієнтуються на теорію, у США більше уваги приділяється практиці. Також кожний університет має свою спеціалізацію, тобто в кожній правничій школі найбільше уваги приділяється своїй, певній галузі права. Найкращою юридичною школою традиційно вважається Гарвард, проте якщо казати, наприклад, про вивчення права інтелектуальної власності, то тут найкращу підготовку може дати Стенфорд за рейтингом 2017 року. Якщо ж казати про міжнародне право, то найкращу освіту в цій сфері дає Нью-Йоркський університет. Вузька спеціалізація дає можливість отримати якіснішу освіту та сприяє успішній конкуренції з іншими правничими школами, яких у США, повторимо, безліч.
Надзвичайно цікавим є підхід до вищої юридичної освіти у Великій Британії. Зокрема, на відміну від інших країн, де вища юридична освіта $\epsilon$ обов'язковою, у Великій Британії можна стати адвокатом без юридичної освіти! Яким чином? Отримавши вищу неюридичну освіту, кожний може пройти так званий GDL (the Gradual Degree of Law). Це навчальний курс, який триває один рік і на якому студент отримує весь необхідний комплекс юридичних знань. Після цього необхідно пройти юридичну практику (the Legal Practice Course, яка також відома як the Postgraduate Diploma in Legal Practice) та стажування в юридичній фірмі. Студентам юридичних факультетів не треба проходити GDL, але юридична практика та стажування $\epsilon$ обов'язковими.

Можливість отримати юридичну освіту протягом одного року $є$ величезною перевагою англійської системи освіти. Адже той, хто вже має одну спеціальність, наприклад IT-технології, поєднавши ії зі знанням законодавства, набагато глибше розуміє, як працює вся система. 3 іншого боку, якщо юридична спеціалізація надзвичайно вузька, то необхідно мати ґрунтовні знання саме в цій сфері [4].

Особливе значення для успішного старту юриста мають практичні навички. Вони здобуваються на стажуванні чи на практиці. В Україні, згідно з чинним законодавством, кандидат мусить мати стаж роботи в галузі права не менше двох років, а після цього - практику саме в адвокатській діяльності.

У Німеччині стажування (Rechtsreferendariat) відбувається впродовж двох років у різноманітних інстанціях: в адвокатурі, прокуратурі, суді, у нотаріаті тощо. Стажування $\epsilon$ оплачуваним. У Франції майбутній адвокат проходить стажування в період останніх шести місяців навчання. У Великій Британії студенти юридичних факультетів починають шукати можливості для стажування вже на останніх курсах навчання. Під час вибору кандидатів для проходження стажування юридичні фірми відштовхуються від рівня успішності студента. Чим вищі бали, тим кращі шанси отримати роботу. Протягом стажування особа проходить практику в різних департаментах фірми. Кількість департаментів і тривалість стажування залежать від сфери, в якій спеціалізується юридична фірма. Пройти стажування надзвичайно складно, оскільки кількість місць для стажування в кілька разів менше кількості випускників юридичних факультетів. Через це в Англії багато випускників юридичних факультетів так і не стають юристами. Якщо все ж таки пощастило отримати бажану посаду, то необхідно щороку проходити спеціальні тренінги й отримати сертифікат успішного проходження такого тренінгу, щоби мати можливість працювати далі.

Вищої юридичної освіти та стажування не досить для того, щоби розпочати адвокатську діяльність. Після того, як студент отримає юридичну освіту, в деяких випадках після проходження стажування він повинен скласти іспит для оцінки рівня знань і готовності до практичної діяльності. $Є$ різні підходи до перевірки знань студента. В Україні майбутньому адвокату необхідно скласти кваліфікаційні іспити. Кваліфікаційні іспити - це перевірка теоретичних і практичних знань заявника в галузі законодавства, історії адвокатури, уміння правильно застосовувати теоретичні знання у практичній діяльності адвоката.

У Німеччині майбутньому адвокату необхідно пройти подвійну перевірку знань і навичок. Після закінчення п'яти семестрів навчання складається перший державний іспит, для складання якого дається лише дві спроби! 
Після складання іспиту видається диплом державного університету Німеччини й можна працювати юридичним консультантом у певних фірмах, але лише в тих, які не спеціалізуються на юридичній проблематиці, наприклад, юристом у певних туристичних фірмах. Другий іспит складається вже після стажування. Цей іспит проводиться під егідою міністерства юстиції відповідної землі. Саме міністерство юстиції вирішує всі організаційні питання: розробляє програму, формує екзаменаційні запитання й екзаменаційну комісію тощо. Варто зазначити, що другий іспит має на меті перевірити не теоретичні знання, а практичні навички, тому і проходить після завершення практики. За статистикою другий іспит складають близько 70-ти відсотків кандидатів.

У США для того, щоби стати практикуючим юристом, необхідно скласти спеціальний іспит (the bar examination) організації адвокатів того штату, в якому ви бажаєте займатись адвокатською практикою. Цей іспит триває чотири дні. У перший день - це тест з етики. Другий - тест на знання законів, що діють на всій території США. Протягом решти двох днів перевіряється знання законодавства, що діє на території того штату, де збирається практикувати кандидат [5, с. 34].

У Франції після проходження курсу навчання складається випускний іспит, після якого в разі успіху видається сертифікат. Іспит доволі жорсткий - складається з письмової й усної частин. Письмова частина має на меті перевірити навички складання юридичних документів. Усна частина іспиту складніше - у ній перевіряється знання різних галузей права, відбувається усна співбесіда іноземною мовою, тією, яку вибрав кандидат, а також співбесіда із членами екзаменаційної комісії про виконання індивідуальної програми.

На сьогоднішній день, в Україні зареєстрували законопроект, яким пропонується удосконалити норми чинного законодавства України про адвокатуру та адвокатську діяльність в частині процедури та особливостей набуття статусу адвоката.

Проект Закону за № 1022011 квітня 2019 р. полягає у внесенні змін до Закону України «Про адвокатуру та адвокатську діяльність» та закріплені положення, що під вищою юридичною освітою слід розуміти другий (магістерський) рівень вищої юридичної освіти, отриманий в Україні, а також вищу юридичну освіту відповідного рівня, здобуту в іноземних державах та визнану в Україні в установленому законом порядку [5].

Законопроект також доповнює частиною 3-1 статтю 8 закону, в якій закріплено вичерпний перелік підстав для відмови у допуску до складання кваліфікаційного іспиту: невідповідність претендента вимогам Закону України «Про адвокатуру та адвокатську діяльність»; невідповідність поданих документів вимогам законодавства; подання не в повному обсязі документів, передбачених Порядком допуску до складення кваліфікаційного іспиту. Проектом запроваджується проведення кваліфікаційного іспиту шляхом проходження анонімного тестування. А також внесено пропозицію про те, що тестування повинна проводити Вища кваліфікаційно-дисциплінарна комісія адвокатури, а організаційно сприяти - кваліфікаційно-дисциплінарні комісії регіонів.

Звільнити від проходження стажування не лише осіб, які мають стаж роботи помічника адвоката не менше одного року за останні два роки, а й осіб, які мають п'ятирічний стаж роботи в галузі права. 3 метою забезпечення ефективної роботи ради адвокатів регіону згідно із законопроектом встановлюються певні ква- ліфікаційні вимоги до Голови такої ради, а саме: безперервний стаж адвокатської діяльності 10 років.

Вищу кваліфікаційно-дисциплінарну комісію адвокатури запропоновано зробити більш незалежною, передбачивши їі підконтрольність і підзвітність виключно 3'їзду адвокатів України, а не Раді адвокатів України

Висновок. Отже, набуття юридичної освіти та статусу представника правничої допомоги в різних країнах світу відрізняється i, відповідно, не позбавлене недоліків. У зв' язку з цим реформування саме в Україні $\epsilon$ необхідним та основоположним. Підвищення статусу адвокатської професії як еліти громадянського суспільства, встановлення єдиних вимог доступу до адвокатської діяльності, рівність осіб, що претендують на набуття статусу адвоката, встановлення єдиних етичних та професійних стандартів адвокатури $є$ благородними цілями реформи адвокатури, що у світлі нових законопроектів, ми сподіваємось, цілком можуть бути реалізованими, проте з урахуванням викладеного, потребують доопрацювання.

\section{Література}

1. Конституція України : офіц.. текст. Київ : КМ, 2016. 96 c.

2. Про внесення змін до Закону України «Про адвокатуру та адвокатську діяльність» (щодо набуття статусу адвоката, відновлення гарантій адвокатської діяльності, удосконалення форм і видів адвокатської діяльності, формування та діяльності органів адвокатського самоврядування) : Проект Закону України від 19 січня 2015 p. № 1794. URL: http://search.ligazakon.ua/l_doc2.nsf/link1/ JH1DU00I.html.

3. Про адвокатуру та адвокатську діяльність : Закон України від 22 червня 2015 p. URL: http: //www.rada.gov.ua.

4. Про Стратегію реформування судоустрою, судочинства та суміжних правових інститутів на 2015-2020 рр. : Указ Президента України від 20 травня 2015 р. № 276/2015. Офіційний вісник Президента України. 2015. № 13. Ст. 33.

5. Проект Закону про внесення змін до Закону України «Про адвокатуру та адвокатську діяльність» щодо доступу до адвокатської діяльності № 10220 від 11 квітня 2019 URL: http://w1.c1.rada.gov.ua. /pls/zweb2/ webproc4_1?pf3511=65806.

6. Реформа адвокатуры: что ждет адвокатов в 2016 году? URL: http://uz.ligazakon.ua/magazine_article/EA008700.

7. Рябцева Е.В. Международно-правовой стандарт адвокатской деятельности. Евразийская адвокатура. 2013. № 4 (5). С. 32-45.

8. Східне партнерство - Співпраця у правовій реформі в країнах східного партнерства; Робоча група «Професійні судові системи»; Доповідь «Професія адвоката». URL: http://www.coe.intt./dghl/cooperation/capacitybuilding/ Source/judic_reform/Eastern\%20Partnership_Report\%20on\%20 Lawyers_English_Final\%20version_15\%2005\%202012.pdf.

9. Про Стратегію реформування судоустрою, судочинства та суміжних правових інститутів на 2015-2020 рр. : Указ Президента України від 20 травня 2015 р. № 276/2015. Офіційний вісник Президента України. 2015. № 13. СТ. 33.

10. Проект Закону про внесення змін до Закону України «Про адвокатуру та адвокатську діяльність» щодо доступу до адвокатської діяльності № 10220 від 11 квітня 2019 p. URL: http://w1.c1.rada.gov.ua./pls/ zweb2/webproc4_1?pf3511=65806.

Чорнобривець В. В., аспірант кафедри державно-правових дисциплін та адміністративного права

Центральноукраїнського державного педагогічного університету імені Володимира Винниченка 